\title{
Oncocytic Neoplasm
}

National Cancer Institute

\section{Source}

National Cancer Institute. Oncocytic Neoplasm. NCI Thesaurus. Code C7072.

A usually benign neoplasm composed of large cells with abundant eosinophilic granular cytoplasm. Representative examples include oncocytic neoplasms of the thyroid gland, and kidney. ( $\mathrm{NCl05)}$ 